Open Access

\title{
On-campus or online: examining self- regulation and cognitive transfer skills in different learning settings
}

Miri Barak ${ }^{1 *}$, Rania Hussein-Farraj ${ }^{2}$ and Yehudit Judy Dori ${ }^{3}$

\author{
* Correspondence: bmiriam@ \\ technion.ac.il \\ ${ }^{1}$ The Faculty of Education in \\ Science and Technology, Technion - \\ Israel Institute of Technology, Haifa, \\ Israel \\ Full list of author information is \\ available at the end of the article
}

\begin{abstract}
This study was set to identify self-regulation skills required for online learning and to characterize cognitive transfer of on-campus and online students. The study included two groups of undergraduate students who studied the same course, but in different settings: online and on-campus. Data collected via an online survey and semi-structured interviews indicated that cognitive strategies and regulation of cognition are significant for successful online learning. Findings also indicated that the online students were more aware of mastery learning and information processing strategies than the on-campus peers. The online students specified the importance of planning, controlling, and evaluation skills for meaningful learning; whereas the on-campus students asserted lack of self-discipline and limited communication skills as barriers for distance learning. Near- and far-transfer components were identified, showing a significant positive correlation with self-regulation skills for both groups of learners.
\end{abstract}

Keywords: Cognitive transfer, Distance education, Higher education, Online learning, Self-regulated learning

\section{Introduction}

The advent of the Internet and mobile technologies and their global diffusion, has created a change in higher education (Barak, 2012; Barak \& Dori, 2009; Peterson \& Roseth, 2016; Vázquez-Abad et al., 2004), especially in the promotion of distance learning (DL) (Abelson, 2008). In recent years, the number of online distance learning courses and programs in academic institutions is increasing drastically (Allen, Seaman, Poulin, \& Straut, 2016; Barak, Watted, \& Haick, 2016). Distance education can provide accessible and affordable education, anywhere, anytime, according to the learners' pace and needs (Allen et al., 2016; Barak, 2012). However, it can lack the direct and personal supervision of the instructor, which might result in learner's sense of isolation and an accompanying lack of engagement (Barak et al., 2016). Studies on the use of advanced technologies indicated that the application of self-regulatory strategies might facilitate the use of cognitive strategies, metacognitive processing, and motivational beliefs (Cho \& Heron, 2015; Kauffman, 2004).

Self-regulated learning (SRL) has been conceptualized in various ways, but the common denominator is the learner's ability to apply the appropriate strategies that positively

(c) 2016 The Author(s). Open Access This article is distributed under the terms of the Creative Commons Attribution 4.0 International License (http://creativecommons.org/licenses/by/4.0/), which permits unrestricted use, distribution, and reproduction in any medium, provided you give appropriate credit to the original author(s) and the source, provide a link to the Creative Commons license, and indicate if changes were made. 
affect her/his learning. These strategies include cognition, metacognition, motivation, and resource management (Sasson \& Dori, 2012; Schraw, 2009; Spruce \& Bol, 2015). In the past three decades, studies indicated a significant relationship between students' use of SRL strategies and their academic accomplishments in the classroom (Boekarts, Pintrich, \& Zeidner, 2000). Various instructional strategies within traditional classroom settings were examined to support and enhance SRL (Hadwin et al., 2011). It is agreed upon that if SRL skills are important to the success of learning in the traditional classroom, then these skills can be expected to play an even more important role for students participating in the distance learning environment (Barnard, Lan, To, Paton, \& Lai, 2009; Kramarski \& Michalsky, 2010). In recent years studies have examined SRL skills in the online environment (Barnard et al., 2009; Hussein-Farraj, Barak, \& Dori, 2012). However, our understanding of SRL in this environment is still in its initial stages (Barnard et al., 2009; Cho \& Heron, 2015).

In addition to SRL, cognitive transfer (of skills and knowledge) is also essential for academic accomplishments and meaningful learning. Cognitive transfer is a process in which the learner is able to function in a new situation (answer questions, solve problems, carryout assignments), according to what s/he learned in a previous situation. In order to achieve cognitive transfer, students must have a sufficient knowledge base to recognize what is required in the transfer environment, and a variety of strategies for dealing with a new situation. Cognitive transfer is thought of as an important feature in SRL research (Boekarts et al., 2000); however, the relation between the two constructs has not yet been reported.

In light of the aforesaid, this study was set to identify self-regulation skills required for online learning and to characterize transfer skills of on-campus and online undergraduate students. This study is based on two assumptions: (a) the more SRL subcomponents a student employs, he or she attains a higher level of self-regulation (Zohar \& Dori, 2012), and (b) a self-regulated student is capable of performing both near and far transfer (Dori \& Sasson, 2013).

\section{Self-regulated learning}

The literature indicates various approaches to self-regulated learning (SRL) derived from a variety of different theoretical perspectives (e.g., Flavell, 1979; Pintrich, 1999; Schraw, 2009). The cognitive model proposed by Flavell (1979) and the SRL model proposed by his followers (Sasson \& Dori, 2012; Schraw, 2009) includes three general components: cognition, metacognition, and motivation. Pintrich (1999) suggested a model that includes: cognitive strategies, metacognitive, self-regulatory strategies, and resource management. Nevertheless, SRL models assume that students are self-regulated learners if they are actively and constructively involved in the learning processes, if they apply metacognitive strategies, and if they are intrinsically motivated (Boekarts et al., 2000; Wolters \& Hussain, 2015). Integrating the work of a group of researchers (Flavell, 1987; Pintrich, 1999; Schraw, 2009), we focus in this paper on three main SRL components: cognition, metacognition, and resource management.

The first component: Cognition, is a group of mental processes that includes the skills necessary to encode, memorize, and recall information (Flavell, 1979). It includes several general types of learning skills, referred to as cognitive strategies or 
thinking skills, problem-solving strategies, and critical thinking skills (Zohar \& Dori, 2012). Cognitive strategies consist of a wide variety of individual tactics that students and instructors use to improve learning (Schraw, 2006). In past and recent studies related to academic performance in the classroom, several key terms such as mastery learning and processing were identified as essential cognitive strategies (Weinstein \& Mayer, 1986; Zohar \& Dori, 2012). These strategies can be applied to simple memory tasks or more complex tasks that require comprehension of information (Rodicio, Sánchez, \& Acuña, 2013; Weinstein \& Mayer, 1986). In our study, we refer to mastery learning, which includes returning to any of the printed or online course materials for the purpose of understanding it better and rethinking. We also refer to processing, which includes summarizing the learning materials, creating analogies, generative note-taking, and question posing.

The second component: Metacognition, is typically viewed as thinking about thinking or demonstrating awareness and understanding of one's cognition (McCormick, 2003; Spruce \& Bol, 2015). Flavell (1979) defined metacognition as awareness of and reflection on one's own cognitive processes, which can induce self-regulation and conscious coordination of learning tasks. The term metacognition is composed of two related components, usually referred to as (Schraw, 2006; 2009). Flavell (1987) first introduced knowledge of cognition, the first metacognitive component, and defined it as knowledge of one's own or someone else's cognition, motivation, or emotions. According to Flavell (1987), knowledge of cognition consists of three major components: personal, task, and strategy. Regulation of cognition is defined as the skill to plan learning strategies, to manage information, to monitor learning, to identify mistakes, and to evaluate the learning (Pintrich, 1999). According to the literature, regulation of cognition consists of three major components: planning, controlling (regulating), and evaluating (Schraw, 2006; Zimmerman, 1995). All self-regulation strategies, previously mentioned, are assumed to improve learning by helping students advance their understanding and academic outcomes (Pintrich, 2000; Wolters \& Hussain, 2015; Zimmerman, 2001). In this study, we examined knowledge of cognition and regulation of cognition, identifying their sub-components in students' assertions.

The third component: resource management is a group of strategies used by students to manage and control their learning environment. Such strategies include managing and controlling their time, effort, study environment, information flow, and other people (Ryan \& Pintrich, 1998). Resource management is assumed to help students adapt to, or change their learning environment to fit their goals and needs. Researchers reported that resource management is important for successful distance learning and a key factor affecting the completion of a course (Hong \& Jung, 2011; Hussein-Farraj et al., 2012). Accordingly, in the present study we examined this aspect, focusing on three sub-components of resource management in an online DL environment: time, place, and information management.

\section{Self-regulation in distance learning}

Several scholars suggested that if SRL skills are important to the success of learning in the traditional classroom (Effat \& Gillies, 2015; Kramarski \& Michalsky, 2010), then these skills can be expected to play an even more important role for students 
participating in the distance learning (DL) environment (Barnard et al., 2009). Many ex-

perts believe that DL environments require the learner to assume greater responsibility for the learning process (Dabbagh \& Kitsantas, 2005; Schunk \& Zimmerman, 1998) and argue that SRL skills are essential to success in these highly autonomous learning situations (Cho \& Heron, 2015; Zimmerman, 2001).

Most learners of all ages have difficulties deploying SRL skills when they are exposed to complex and challenging topics in open-ended learning environments (Azevedo, 2005; Wolters \& Hussain, 2015). Effective SRL strategies might be critical in DL situations given the high degree of student autonomy resulting from the instructor's physical absence. Unfortunately, not all students are self-regulated learners (Cho \& Heron, 2015). Many are unmotivated and fail to use cognitive strategies, thinking skills, or do not have self-monitoring ability (Cho \& Heron, 2015). Students lacking SRL skills may misinterpret the autonomy of the DL environment and, as a result, may not accomplish the learning tasks as expected in DL courses (Barnard et al., 2009). In order to examine this notion, this study was set to characterize self-regulation and cognitive transfer skills in on-campus and online distance learning environments.

\section{Cognitive transfer skills}

Cognitive transfer is defined as applying domain knowledge and skills from one domain to new learning situations (Perkins \& Salomon 1988; Sasson \& Dori, 2012). It is conceptualized as the personal construction of relations of similarity (Forsyth, 2012; Lobato, 2008). There is disagreement among researchers on the nature of cognitive transfer, the extent to which it occurs, and the nature of its underlying mechanisms (Lobato, 2008). However, the educational community agrees that to achieve cognitive transfer, one must have a sufficient knowledge base to recognize what is required in the transfer environment (Glaser, 1986), and a variety of thinking skills for dealing with new skill sets required for solving a new task (Detterman, 1993; Dori \& Sasson, 2013).

Two types of cognitive transfer - near and far - are often distinguished (Detterman, 1993). Near transfer occurs when the new learning situation is similar to a previous situation and differs from it only slightly. In contrast, far transfer occurs when students have to perform in a new learning situation with different patterns from those to which they were accustomed (Detterman, 1993). Dori and Sasson (2013) elaborated on this definition by claiming that near transfer occurs when the new learning situation requires application of a relatively small set of skills that revolves around the same discipline content, and uses features similar to previous learning situations to which the student was exposed. Far transfer occurs when a student has to perform in a new and different learning situation that requires application of skills and knowledge from one or more disciplines other than the one in which the learning originally took place.

Designing learning environments to foster students' cognitive transfer of both knowledge and skills is a major educational goal (Detterman, 1993; Dori \& Sasson, 2013; Forsyth, 2012; McCrudden, 2011). These researchers investigated the role of relevance instructions on cognitive transfer skills and methods for encouraging transfer between in-school and out-of-school learning. However, there is a dearth of studies that investigate the relationship between cognitive transfer and SRL in a DL environment. Our 
study was set to provide some insights into the relationship between the two constructs.

\section{Method}

\section{Research objective and participants}

The research objective was to identify self-regulation skills required for online learning and to characterize transfer skills of on-campus and online undergraduate students. This goal raised the following two research questions:

1. What self-regulation skills are required for online learning according to on-campus and online students?

2. What characterizes on-campus and online students' transfer components and their relationship with SRL?

The research included 84 science and engineering undergraduates who studied the same course - Educational Psychology, but in a different learning environment: online distance learning $(N=29)$ and on-campus face-to-face $(N=55)$. In both groups, gender distribution was about equal (51 \% males and $49 \%$ females), and the majority of students ( $88 \%$ ) between the ages of 18 to 29 . About half of the population - $52 \%$ majored in engineering, $27 \%$ majored in science education, and $21 \%$ in pure sciences. Among them, 16 students agreed to be interviewed; ten from the online distance learning (DL) group and six from the on-campus, face-to-face (F2F) group (see Appendix 1).

\section{Research settings}

The online and on-campus Educational Psychology courses were delivered in parallel by the same lecturer and teaching assistants. They included the same learning assignments and requirements. Educational Psychology course was selected for our research for both purposeful and convenience sampling reasons (Forman, Creswell, Damschroder, Kowalski, \& Krein, 2008). We wanted to examine SRL and transfer components in a context that is remote from the students' major learning subjects: science and engineering (purposeful sampling), and we received full support and cooperation from the teaching staff and the students (convenience sampling).

The objective of the Educational Psychology course was to promote an understanding of the fundamental issues of social and cognitive psychology among science and engineering students. The course assignments included reading professional papers and analyzing case studies, while referring to psychological concepts and principles toughs in the course. The on-campus students completed and presented their assignments in the classroom, whereas the online distance-learning students conducted and submitted the same assignments online.

\section{Data sources}

The mixed method research model was applied, using both quantitative and qualitative methodologies in the analysis and data interpretation (Creswell, 2008; Forman et al., 2008). The study included two tools: an online survey and semi-structured interviews, detailed in the following paragraphs. 
The online survey was administered at the end of the semester to identify selfregulated learning and transfer components according to the on-campus and online students' assertions. The survey included two open-ended assignments. First, students were required to describe their learning process and elaborate on their views about online learning. Second, they were asked to pose at least two questions related to the psychology course that interest or concern them most. The answers to the first assignment were analyzed to identify SRL components for successful online learning, according to the students' learning process and interests. The answers to the second assignment were analyzed to identify transfer skills, based on the literature that shows that question posing can serve as a mean for identifying students' knowledge and thinking skills (Barak \& Rafaeli, 2004; Sasson \& Dori, 2012). The survey granted two points of credit in order to minimize the possibility of individual variations regarding response rate.

The semi-structured interviews were conducted at the end of the semester to examine science and engineering students' learning processes and identify SRL components. The interviews were managed as a conversation based on questions and answers that the interviewer used to navigate the interview. Sixteen students volunteered to be interviewed, ten from the online DL group and six from the on-campus F2F group. Their demographics are presented in Appendix 1. The interviews with the on-campus students were conducted in person; while the interviews with the DL students were conducted via Skype (http://www.skype.com). Each interview took about $45 \mathrm{~min}$, audiotaped via Audacity application (http://audacity.sourceforge.net) and accompanied by a research diary.

\section{Data analysis}

The content analysis of students' assertions was conducted in four steps, according to the directed content analysis approach (Hsieh \& Shannon, 2005). First, we collected, read, and re-read the students' responses to the open assignments, organizing them in two lists: the assertions of the on-campus students and those of the online students. Second, the descriptions of students' learning process and the questions they posed were divided into short segments, each representing a 'unit of meaning'. Third, based on SRL literature (Pintrich, 2000; Schraw, 2009; Zimmerman, 1989), each 'learning process' segment was classified under SRL component or sub-component. Similarly, each 'question' segment was categorized and classified under near or far transfer components (Dori \& Sasson, 2013). Finally, the segments that indicated SRL and transfer skills were coded, assigned with nominal numbers, and frequencies were calculated. This process resulted in the characterization of SRL and the identification of transfer sub-components and components. A similar process was conducted in order to identify transfer components and to classify them to near and far transfer (Sasson \& Dori, 2012). The transfer coding was determined by the number of components that were identified in the students' assertions. Components defined as near transfer scored one point because of their proximity to the course content, and components defined as far transfer scored two points because they applied knowledge from one domain (psychology) to another (everyday life). An example for content analysis and data coding is presented in Appendix 2. 
The trustworthiness, reliability, and validity of the analysis were established through data and investigators triangulation via three experts in science education (Denzin \& Lincoln, 2005), with interrater agreement of $95 \%$. To examine differences between the research groups (DL and F2F) in their SRL and transfer skills, data were statistically analyzed via the Mann-Whitney model, a nonparametric test used in cases where normal distribution cannot be assumed and samples differ in size (Conover, 1999).

\section{Findings}

This section includes two parts; each provides an answer to one of the research questions. The first section describes the SRL components that were identified in students' statements about online learning. The second section characterizes students' transfer components and their relationship with SRL.

\section{Self-regulation skills required for online learning}

Following the literature on SRL and the content analysis of students' statements about their learning process, we identified four main SRL components: Cognitive strategies (Cognition), Knowledge of cognition (Metacognition), Regulation of cognition (Metacognition), and Resource management. Altogether, we collected 421 statement segments from both groups; 247 from the on-campus F2F students and 174 by the online DL students. Figure 1 presents their distribution by research group.

The graph in Fig. 1 shows that cognition was the least common SRL component among both groups of students. This result does not indicate a lack of cognitive abilities; rather, that they are more aware and concern of metacognitive aspects, such as knowledge and regulation of cognition, as well as resource management aspects. A comparison between the two research groups indicated that online students provided more statements related to cognitive strategies and regulation of cognition (8\% and $42 \%$, respectively) than on-campus F2F students (5\% and $17 \%$, respectively). These results suggest that online students are self-conscious about mastery learning and information processing with relation to learning from distance. The online DL environment enabled students to recite and summarize different parts of the lecture and to assemble all parts to generate a better understanding of the learning materials. In addition, the

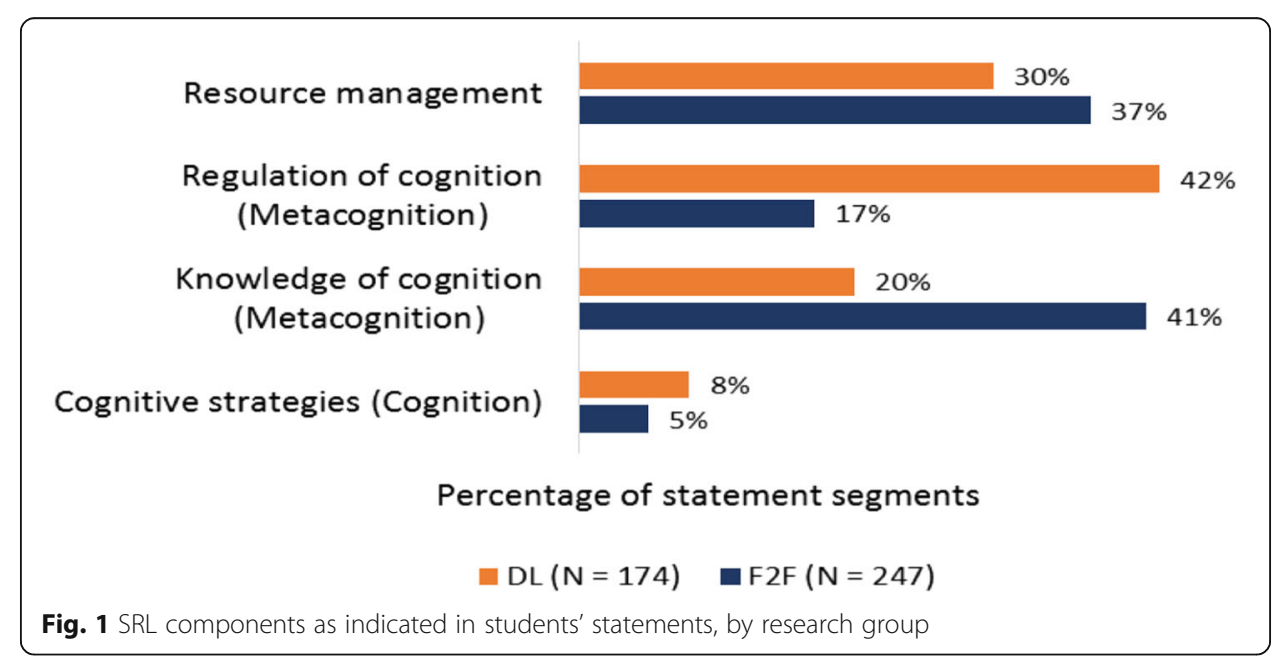


DL students indicated better planning, controlling, and evaluation skills for their learning process than their F2F counterparts.

In contrast, F2F students provided more statements related to knowledge of cognition and resource management (41\% and $37 \%$, respectively) than DL students (20\% and $30 \%$, respectively). F2F students stated that they have little self-discipline to learn from distance and that they were concerned with the fact that in online settings they might not have enough interactions with one another and the lecturer. As part of the resource management component, F2F students claimed that they come to the campus for other courses and that distance learning does not give them any advantage. In contrast, online DL students pointed out that learning from a distance gives them flexibility with respect to time, pace, and place. Table 1 presents selected examples of DL and F2F students' statements identified as SRL components.

Concerning Cognitive strategies, the DL and F2F students presented similar statements about mastery learning. Students in both groups agreed that since the lecture videos can be replayed as often as needed, they can better summarize the learning materials. However, the DL students emphasized the importance of processing, indicating strategies for summarizing the learning material, for creating analogies, and for note taking. It seems that the online students were more aware of the importance of information processing strategies.

For example, Sara, a Biomedical engineering student who took the course online, asserted: "Distance learning is a big advantage, I can summarize and process the learning materials, write notes and comments ...do it my own way, looking for more explanations on the web to better understand the new concepts. Contrary to this, Noreen, an Industrial Engineering student who took the regular course asserted that: Distance learning requires the ability to concentrate and autonomously process the information presented in the articles and the lecture videos... I am not sure that am able to learn in such a way, I rather be in the classroom.

Table 1 Examples of SRL skills identified in students' statements about their learning process

\begin{tabular}{|c|c|c|c|}
\hline Main component & Sub-component & Group & Examples \\
\hline \multirow[t]{2}{*}{ Cognition: cognitive strategies } & Mastery learning & $\mathrm{DL}$ & $\begin{array}{l}\text { In distance learning, I can repeat the point that } \\
\text { I did not understand as much as I want. }\end{array}$ \\
\hline & & $F 2 F$ & $\begin{array}{l}\text { Online learning can be beneficiary due to the } \\
\text { lecture videos that can be repeatedly viewed. }\end{array}$ \\
\hline \multirow[t]{2}{*}{$\begin{array}{l}\text { Metacognition: Knowledge } \\
\text { of cognition }\end{array}$} & Social & $\mathrm{DL}$ & $\begin{array}{l}\text { About the online forums, participating in the } \\
\text { same learning group throughout the semester, } \\
\text { strengthens the interactions between the students } \\
\text { and conveys more lengthy discussions. }\end{array}$ \\
\hline & & $\mathrm{F} 2 \mathrm{~F}$ & $\begin{array}{l}\text { I did not choose to learn from distance because } \\
\text { it is very important for me to be able to interact } \\
\text { with the lecturer in a direct and personal matter. }\end{array}$ \\
\hline \multirow[t]{2}{*}{$\begin{array}{l}\text { Metacognition: Regulation } \\
\text { of cognition }\end{array}$} & Controlling & $\mathrm{DL}$ & $\begin{array}{l}\text { In distance learning, I do not need to adjust myself, } \\
\text { I can learn slowly in my own pace. }\end{array}$ \\
\hline & & $\mathrm{F} 2 \mathrm{~F}$ & $\begin{array}{l}\text { While learning in the classroom, I rarely listen } \\
\text { to the lecturer, so actually, I could have learned } \\
\text { the course from distance. }\end{array}$ \\
\hline \multirow[t]{2}{*}{ Resource management } & Time & $\mathrm{DL}$ & $\begin{array}{l}\text { Distance learning does not limit me in time. } \\
\text { I do not need to attend class at a specific time. }\end{array}$ \\
\hline & & $\mathrm{F} 2 \mathrm{~F}$ & $\begin{array}{l}\text { DL is more suited for working people that do } \\
\text { not have time to come to the campus. }\end{array}$ \\
\hline
\end{tabular}


Concerning Knowledge of cognition, our findings indicated three attributes related to personal aspects: affective, self-discipline, and knowing myself as a learner. According to the students' assertions, these three attributes can facilitate productive learning in online environment, when they are positively applied. 'Affective' refers to students' feelings about learning from distance, their reaction toward the virtual learning environment, and how they perceive the online course (contents and assignments). For example: I like learning from distance, I enjoy the idea that I can be anywhere and still be able to hear the lecture and do my assignments. (Avi, an online student, studying Industrial Engineering).

'Self-discipline' comes after the initial enthusiasm, helping students regulate their learning by taking responsibility and actions to pursue their learning goals. For example: I am aware of my responsibility, I can only trust myself ... if I do not watch the videos or thoroughly read the articles, I will not understand the learning materials and probably fail the course. (Soraya, an online student, studying Science Education).

'Knowing myself as a learner' refers to the need to be familiar with one's own strength and weaknesses as a learner and taking actions to prosper in a certain learning situation. For example: I am easily distracted by people or noise; this is why, I prefer to learn on my own in a quite environment. (Raz, an online student, studying Science Education). Another example: I am more productive in the evenings... it is difficult for me to concentrate in the mornings. (Avi, an online student, studying Industrial Engineering).

Overall, the online students indicated positive assertions related to the three attributes. They indicated positive feelings about online learning, strong motivation to complete the online course, and they felt confident about their learning abilities. On the other hand, the F2F students described personal barriers for learning online, such as low self-discipline, and were concern about not being able to learn effectively in an online environment. For example, Kamila, an online student, studying Industrial Engineering asserted: Distance learning can be a good idea if you have a strong will and self-discipline. In my case, it is a problem since I tend to postpone things.

Regarding social aspects, the DL students emphasized the importance of interactions with the lecturer and fellow students, indicating social learning as an important feature of distance education. For example: the online forums encouraged effective communication... I participated when I needed an answer and either one of the students or the TAs responded. (Ben, an online student, studying Industrial Engineering).

Another example: participating in the same learning group throughout the semester, strengthened our interactions and conveyed interesting discussions. (Josef, an online student, studying Computer Science).

Contrary to this, The F2F students indicated concerns about not having sufficient communication with the teaching team, viewing it as an obstacle to online learning. For example, Lili an Industrial Engineering student, asserted: I did not choose to learn from distance because the direct interactions with the lecturer are very important to me.

In addition, statements related to task and strategy indicated that the DL students were aware of the steps needed to be taken to study the course; whereas the F2F students were mostly concerned about being able to ask questions during the lecture period. 
Concerning Regulation of cognition, students from both groups indicated the importance of careful planning for successful online learning. However, the F2F students provided negative statements, indicating low planning abilities. For example: $I$ choose not to learn from distance because I am not good in planning a learning schedule. (Basel, an on-campus student, studying Civil Engineering).

Regarding controlling, the DL students seemed better at controlling their learning process than their F2F peers. For example, Avi, an Industrial Engineering student, asserted: ...in online learning, I can control various aspects of learning, including the lecture videos, which I can fast forward, stop, or replay. Students from both groups thought that online environments are effective method for evaluation, indicating the importance of immediate feedback and the ability to monitor their grades.

Concerning Resource management, the DL students emphasized the importance of being independent and self-governing with relation to time and place of learning. F2F students stated that online learning is suitable for people who work and have no time to come to the campus, while they have no time limitations and can reach campus on a daily basis. Both DL and F2F students presented similar statements regarding the importance of managing information. They stated that effective online learning relies on the organization of the course website. For example: When I was asked to perform a task, it is easy for me to find the information on the course website. For example, for the conformity assignment, I used the lecture notes and the related articles ... all the information was presented online in an orderly way, and in my opinion this arrangement is very convenient. (Marcy, an online student, studying Industrial Engineering).

Based on previous work (Pintrich, 1999; Schraw, 2006; Zimmerman, 1989, Zohar \& Dori, 2012), Fig. 2 presents a summary of the SRL components as were identified in this study. Our findings contribute two new sub-components: social in the 'Knowledge of cognition' domain, and place in the 'Resource management' domain.

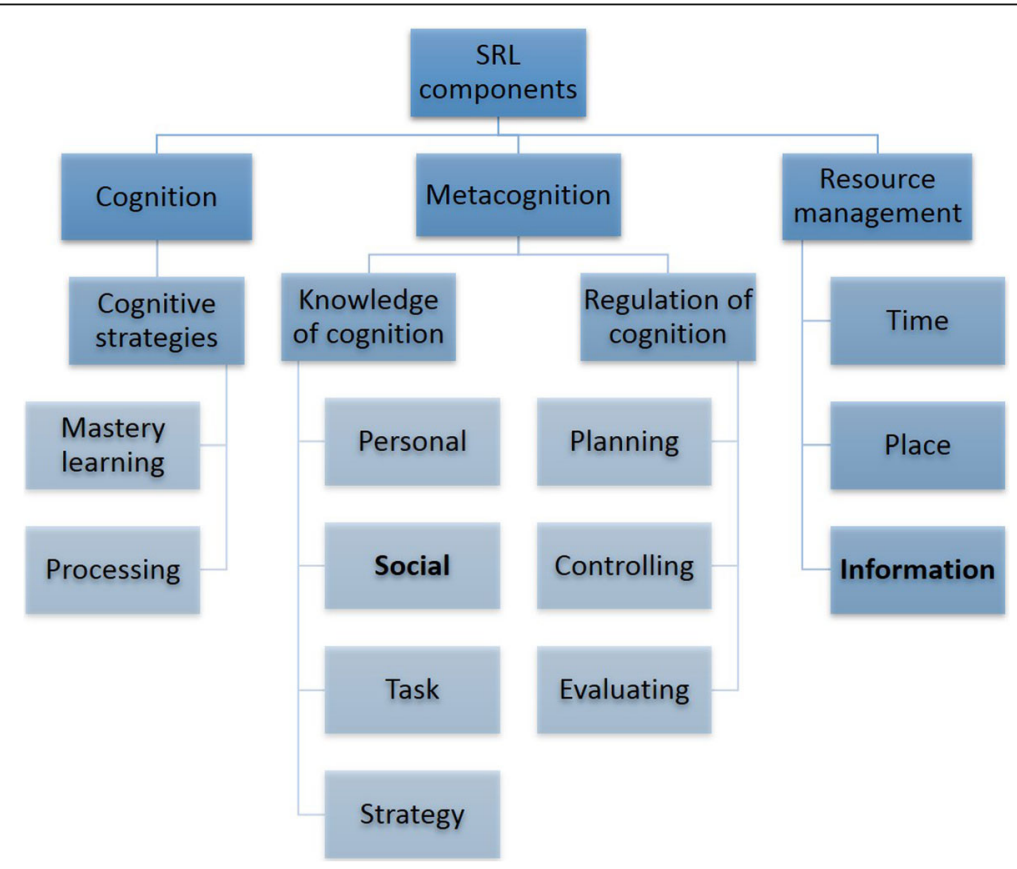

Fig. 2 SRL components identified in students' statements about their learning process 


\section{Students' transfer components and their relationship with SRL}

Altogether, students from both groups posed 198 questions; 112 by the on-campus F2F students and 86 by the online DL students. Among them, 68 questions (34\%) were identified as 'near transfer' (related to the course contents) and the rest, 130 questions (66 \%) were identified as 'far transfer'. The far transfer questions were divided to three main components: Personal aspects, Family situation, and Professional career. These components were considered as cognitive transfer because they indicated students' ability to associate knowledge from one domain (educational psychology) to new situations.

Regarding near transfer, analysis indicated that both F2F and DL students posed similar percentages of questions related to course content (30 and $26 \%$, respectively). Further analysis showed that the F2F students' questions were associated with knowledge or comprehension - lower-order cognitive skills, while the DL students' questions were associated with application - a higher-order cognitive skill. It seems that while F2F students were concerned about acquiring knowledge, the DL students were concerned about how to apply their knowledge effectively. For example, Rana, an oncampus student in Science Education, posed the following question: What are the ways to identify social isolation? Sara, an online student in Biomedical Engineering, wrote: I would like to learn more about leadership development in practice - not just what are the features, but tools that can help me achieve it.

Regarding far transfer, analysis indicated that the online DL students posed more questions associated with family situation than the F2F students (23\% and $5 \%$, respectively). For example: What is the best way to deal with children's behavioral problems? (R.K., male, an online student in Biology, online survey), or How can a dispute between a married couple be resolved with psychological tools? (G.A. male, an online student in Industrial Engineering, online survey). This can be explained by the fact that more than a third of the students who elected to study from distance were married, and some had parental responsibility.

Contrary to this, the on-campus F2F students posed more questions associated with personal aspects than the DL students (49 and $19 \%$, respectively), raising concerns about their learning abilities or issues related to relationships with others. For example: Does the exposure and development of awareness to behavioral phenomenon change the individual's behavior? (L.D., female, an on-campus student in Science Education, online survey) or How can Educational Psychology help me learn more efficiently and exploit class time better? (M.S., male, an on-campus student in Mechanical engineering, online survey).

Regarding professional career in industry or organizations, the online DL students posed more questions than the F2F students (32 and $16 \%$, respectively). For example: As a new employee, when and how can I express professional opinions which contradict my manager's opinion? (N.S., female, an online student in Industrial engineering, online survey). This can be explained by the fact that more than $60 \%$ of the online students were working part time in the industry or various companies. They were concerned about their behavior in the workplace and their professional advancement. Figure 3 presents a summary of the cognitive transfer components - near transfer (NT) and far transfer (FT), as were identified in the question-posing assignment. 


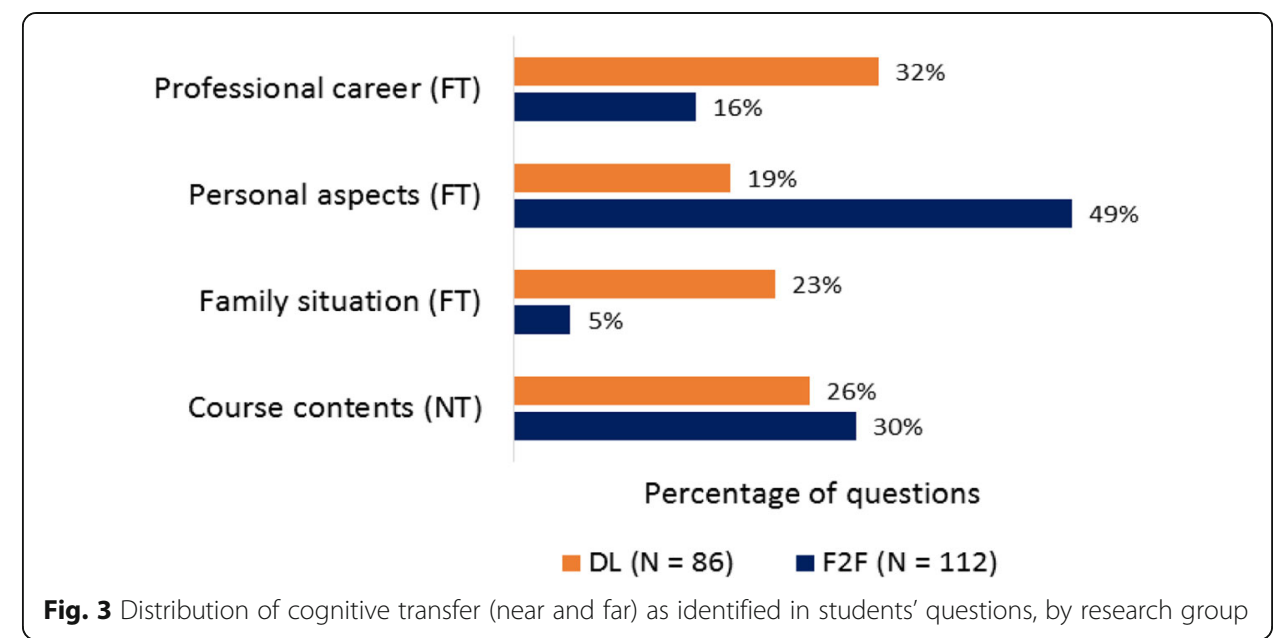

The identification and codification of the transfer and SRL components enabled the comparison between DL and F2F students, using Mann-Whitney test. Means, standard deviations, and the results of the $U$-test, are presented in Table 2 .

Table 2 shows that the DL students indicated statistically significant higher means for both SRL and transfer skills than the F2F students. These results may explain students' performance in the final examination and final project. Data indicated that, the DL students received higher mean scores in the final examination compared to their F2F peers (Mean $=73.20, \mathrm{SD}=8.53$; Mean $=66.64, \mathrm{SD}=11.23$, respectively) with a statistically significant difference $(U=530.50, p=.009)$. The DL students also received higher mean scores in the final project compared to the F2F students (Mean = 92.54, $\mathrm{SD}=7.51$; Mean $=83.16, \mathrm{SD}=14.07$, respectively) with a statistically significant difference $(U=384.50, p=.000)$. Spearman correlation test indicated a statistically significant positive correlation between the SRL and transfer components (Spearman's $r h o=0.28, p<.01)$. This suggests that students, who asserted high SRL skills, also indicated high levels of transfer skills, and vice versa.

\section{Summary and discussion}

\section{Self-regulation skills required for online learning}

Online distance learning courses and full programs are becoming popular in higher education as they are considered to be cost-effective and meet institutional strategies for reaching out to diverse population of students (Allen et al., 2016; Barak et al., 2016; Peterson \& Roseth, 2016). From the students' perspective, online distance learning courses provide flexibility in time, place, and pace (Barak et al., 2016; Peterson \& Roseth, 2016). The rapid development of distance learning courses necessitates better

Table 2 Mann-Whitney test for SRL and Transfer components by research groups

\begin{tabular}{|c|c|c|c|c|c|c|c|c|c|}
\hline \multirow[t]{2}{*}{ Skill } & \multirow[t]{2}{*}{$n^{a}$} & \multicolumn{3}{|c|}{ DL students $(N=29)$} & \multicolumn{3}{|c|}{ F2F students $(N=55)$} & \multirow[t]{2}{*}{$U$ test } & \multirow[t]{2}{*}{$p<$} \\
\hline & & Mean & SD & $\overline{M i n-M a x}$ & Mean & SD & $\operatorname{Min}-\operatorname{Max}$ & & \\
\hline SRL & 198 & 3.68 & 1.55 & $0-6$ & 2.31 & 1.55 & $0-8$ & 441.50 & 0.001 \\
\hline Transfer & 421 & 5.88 & 2.80 & $0-13$ & 4.33 & 2.30 & $0-11$ & 563.00 & 0.05 \\
\hline
\end{tabular}

${ }^{a} n$ number of statement segments or posed questions 
understanding of the learning process in the online environment. Online learning eliminates the limitation of place, time, and pace, providing students with a high degree of freedom. This gives students autonomy and control over where, when, and how to study (Hong \& Jung, 2011; Peterson \& Roseth, 2016).

Since distance online learning is characterized with autonomy, students' ability to self-regulate their learning becomes a critical factor for deep and meaningful learning (Barnard et al., 2009; Hussein-Farraj et al., 2012). Researchers have indicated the enhancing effects of self-regulatory skills on academic performance in traditional classrooms (Boekarts et al., 2000; Hadwin et al., 2011; Wolters \& Hussain, 2015). Therefore, the understanding of SRL in online learning is significant for both instructors and students as this might positively influence learning outcomes and cognitive development (Barnard et al., 2009; Kramarski \& Michalsky, 2010).

The findings of this study support this assertion. Data indicated that both oncampus and online students maintained that successful online learning relies on 'cognitive strategies' and 'regulation of cognition' (a metacognitive skill). The online students indicated metacognitive skills, such as planning, controlling, and evaluation skills, as essential for meaningful distance learning; while the on-campus students asserted lack of self-discipline and limited communication skills as barriers to distance learning.

Our findings are consistent with the work of Hong and Jung (2011), who reported that cognition and metacognition skills seem to be among the more influential skills that explain distance learners' success. Studies indicated that technology-enhanced learning environments could support self-regulatory learning skills by providing opportunities for self-monitoring, mastery learning, peer interactions, and methods for cognitive apprenticeship (Barnard et al., 2009; Cho \& Heron, 2015; Kramarski \& Michalsky, 2010).

'Knowledge of cognition' is another metacognitive skill that was highly represented. It is an important component of self-regulated learning that consists of personal, task, and strategy (Flavell's, 1987). In this study, we identified a fourth sub-component: 'social' that was highly expressed by the online students. The students asserted that by receiving support from peers and instructors in the online environment, they were better able to regulate their learning and become more confident as learners. This is in line with the findings of recent studies that indicated the importance of peer support and scaffolding for self-regulation in the classroom (Effat \& Gillies, 2015) and in online environments (Rodicio et al., 2013).

Meaningful and effective learning depends on students' ability to manage resources in such a way that will fit their goals and needs (Pintrich, 1999; Wolters \& Hussain, 2015). In this study, we identified time and place as two components of 'resource management', as was indicated in previous studies (Pintrich, 1999; Zohar \& Dori, 2012). We also identified a third component: 'information management', which was not yet indicated in the literature. Similar to previous studies, in this study we found that efficient resource management is critical for successful online learning (HusseinFarraj et al., 2012; Selim, 2007). The online students asserted that the availability of the online materials on the course website and the use of the video-streaming platform helped them to manage, control, and handle the volume of information. Learning environments and activities that facilitate efficient resource management are 
significant for students' learning process and academic success (Pintrich, 1999; Zohar \& Dori, 2012).

\section{Cognitive transfer skills}

In addition to promoting self-regulated learning, successful learning environments facilitate students' cognitive transfer skills by taking into account their individual needs and preferences (Ford, Smith, Weissbein, Gully, \& Salas, 1998; McCrudden, 2011; Sasson \& Dori, 2012). In this study, we examined cognitive transfer components as indicated in the questions that students posed. Both oncampus and online students asserted near and far transfer by applying concepts and principles, taught in the psychology course (i.e. domain knowledge and skills), to new situations. However, the two groups differed in three main aspects. The first difference is related to the way they applied the psychological concepts. The on-campus students connected them to personal aspects, while the online students connected them to professional advancement and family situations. This can be explained by the fact that most of the students who chose to learn from distance are already on the job market and have family responsibilities (as indicated in Appendix 1).

The second difference between the two research groups is related to the transfer component that concerns 'course contents'. While the on-campus students referred to acquiring knowledge, the online learning students were more concerned about application of knowledge, a higher cognitive skill. This result strengthens the claim that distance learning does not detract from the quality of the learning process (Hussein-Farraj et al., 2012). It also strengthens the claim that by providing students with relevance instructions, their transfer skills can be enhanced (McCrudden, 2011; Sasson \& Dori, 2012).

The third difference between the two research groups is related to their learning abilities. The online students indicated no concerns about their learning abilities; they were self-confident about their ability to learn from distance. The on-campus students, on the other hand, asserted questions related to how educational psychology can help them as learners. These findings are in accordance with the transfer skills framework proposed by previous studies (Dori \& Sasson, 2013; Sasson \& Dori, 2012).

Overall, our findings indicated that students who took the online course, received higher means for both SRL and transfer skills, compared to the oncampus group. They also received higher mean scores on their final project and examination. This might suggest a strong preference for online learning. However, this is not the case. Only a third of the course students chose to study it online. Most of the students still prefer to learn in a traditional, face-to-face, classroom setting. Hence, higher education institutions should consider providing students with the opportunity to choose their preferred learning environment. Their choice can depend upon their personal situation (commitment to workplace, family situation, commuting difficulties, etc.) or type of course (mandatory/elective, lecture, seminar, tutorial etc.) This will enable students to explore different instructional settings and choose the one that most suites them at a certain period 
of their life. This adheres to the notion of adaptive education and life-long learning.

\section{Limitations and contributions}

This exploratory study was conducted through a strict data analysis process to establish trustworthiness by means of validity and reliability. However, as in most studies, there are limitations that should be noted. First, the study was conducted in one higher education institution with a relatively small number of participants - eighty-four science and engineering students. Although the demographics of our population was similar to that of other science and engineering universities, further examination should be conducted in order to expand generalizability. This can be done by conducting similar studies in diverse learning situations and educational contexts to include learners from different disciplines, age groups, and nationalities.

Second, the participants were self-selected into the two research groups: on-campus and online. In experimental studies, self-selection makes it difficult to determine causality. However, a randomized selection of students to either of the research groups would have forced some of the students to learn in an environment they felt to be unfit, thus potentially causing an ethical problem and resulting in students' opposition and lack of willingness to learn (Virnoche, 2008).

Overall, our study adds another layer to the growing body of knowledge on students' preferred learning environments - on-campus vs. online and their considerations when choosing (or not) to learn from distance.

\section{Appendix 1}

Table 3 Demographic background of F2F and DL science and engineering interviewees

\begin{tabular}{|c|c|c|c|c|c|c|}
\hline Research group & Pseudonyms & Gender & Age range & Faculty $^{a}$ & Marital status + children & Workplace \\
\hline \multirow[t]{10}{*}{$\mathrm{DL}$} & Sara & Female & $20-25$ & Bio. Eng. & Single & - \\
\hline & Marcy & Female & $25-30$ & Ind. Eng. & Single & Hi-tech company \\
\hline & Rayan & Female & $20-25$ & Ind. Eng. & Married & - \\
\hline & Soraya & Female & $25-30$ & Sci. Educ. & Married + & Science Laboratory \\
\hline & Avi & Male & $25-30$ & Ind. Eng. & Married + & - \\
\hline & Ben & Male & $25-30$ & Ind. Eng. & Single & Hi-tech company \\
\hline & Josef & Male & $25-30$ & Comp. Sci. & Married + & Hi-tech company \\
\hline & Ron & Male & $25-30$ & Biology & Single & Psychometric firm \\
\hline & Raz & Male & $40-45$ & Sci. Educ.. & Married + & Shipping company \\
\hline & Ziv & Male & $25-30$ & Ind. Eng. & Single & Shipping company \\
\hline \multirow[t]{6}{*}{$\mathrm{F} 2 \mathrm{~F}$} & Rana & Female & $18-20$ & Sci. Educ. & Single & - \\
\hline & Noreen & Female & $25-30$ & Ind. Eng. & Single & - \\
\hline & Kamila & Female & $21-25$ & Ind. Eng. & Single & - \\
\hline & Lili & Female & $21-25$ & Ind. Eng. & Single & - \\
\hline & Basel & Male & $21-25$ & Civil Eng. & Single & - \\
\hline & Oded & Male & $25-30$ & Sci. Educ. & Married & Hi-tech company \\
\hline
\end{tabular}

${ }^{a}$ Faculty abbreviations: Bio. Eng. Biomedical Engineering, Civil Eng. Civil Engineering, Comp. Sci. Computer Science, Ind. Eng. Industrial Engineering, Sci. Educ. Science Education 


\section{Appendix 2}

The following paragraphs present two examples of content analysis and coding of SRL and transfer components for the same student - Rayan who studied the course from distance. The first example presents Rayan's description of her learning process and the SRL coding:

DL enables learning on my own time [Time]. If I am tired and not concentrated, I can stop the video lecture [Controlling], and if I do not understand something, I can go back to the lecture as many times as I need [Mastery learning]. I can summarize the material [Processing] on my own pace [Controlling], and therefore, I plan to choose a DL course in the next semester.

In this example, five SRL components were identified; therefore, her assertion received five 'SRL points'.

The next example presents Rayan's questions and the transfer coding:

What areas in psychology are considered prominent among educational psychologists in the last decade? [Knowledge of course content - Near transfer].

What are the ways to calm down crying children (ages 3-to-4)? [Parenthood - Far transfer].

How can we apply social psychology principles to improve interpersonal relationships? [Interpersonal relations - Far transfer].

In this example, one question was identified as 'near transfer' (receiving one point) and two questions were identified as 'far-transfer' components, each receiving two points; therefore, Rayan received five 'cognitive transfer points'.

\section{Authors' contribution}

$\mathrm{MB}, \mathrm{RH}-\mathrm{F}$, and YJD planned the research, carried out data collection and analysis, and drafted the manuscript. All authors read and approved the final manuscript.

\section{Competing interests}

The authors declare that they have no competing interest.

\section{Author details}

${ }^{1}$ The Faculty of Education in Science and Technology, Technion - Israel Institute of Technology, Haifa, Israel. ${ }^{2}$ The Department of Education, Sakhnin College, Sakhnin, Israel. ${ }^{3}$ The Faculty of Education in Science and Technology, Technion - Israel Institute of Technology, Haifa, Israel.

Received: 1 June 2016 Accepted: 1 September 2016 Published online: 01 November 2016

\section{References}

Abelson, H. (2008). The creation of OpenCourseWare at MIT. Journal of Science Education and Technology, 17(2), 164-174.

Allen, I. E., Seaman, J., Poulin, R., \& Straut, T. T. (2016). Online report card: tracking online education in the United States. Babson Park: Babson Survey Research Group. Retrieved from Education Advisory Board Website: http://onlinelearningsurvey.com/reports/onlinereportcard.pdf.

Azevedo, R. (2005). Using hypermedia as a metacognitive tool for enhancing student learning? The role of selfregulated learning. Educational Psychologist, 40, 199-209.

Barak, M., \& Dori, Y. J. (2009). Enhancing higher order thinking skills among in-service science teachers via embedded assessment. Journal of Science Teacher Education, 20(5), 459-474.

Barak, M. (2012). Distance education: towards an organizational and cultural change in higher education. The Journal of Enterprising Communities: People and Places in the Global Economy, 6(2), 124-137.

Barak, M., \& Rafaeli, S. (2004). Online question-posing and peer-assessment as means for Web-based knowledge sharing. International Journal of Human-Computer Studies, 61(1), 84-103.

Barak, M., Watted, A., \& Haick, H. (2016). Motivation to learn in massive open online courses: examining aspects of language and social engagement. Computers \& Education, 94, 49-60. doi:10.1016/j.compedu.2015.11.010. 
Barnard, L., Lan, W. Y., To, Y. M., Paton, V. O., \& Lai, S.-L. (2009). Measuring self-regulation in online and blended learning environments. Internet and Higher Education, 12, 1-6. http://dx.doi.org/10.1016/j.iheduc.2008.10.005.

Boekarts, M., Pintrich, P. R., \& Zeidner, M. (Eds.). (2000). Handbook of self-regulation: theory, research and applications. San Diego: Academic.

Cho, M.-H., \& Heron, M. L. (2015). Self-regulated learning: the role of motivation, emotion, and use of learning strategies in students' learning experiences in a self-paced online mathematics course. Distance Education, 36(1), 80-99.

Conover, W. J. (1999). Practical nonparametric statistics (3rd ed.). Hoboken: Wiley.

Creswell, J. W. (2008). Educational research: planning, conducting, and evaluating quantitative and qualitative research (3rd ed.). Upper Saddle River: Prentice Hall.

Dabbagh, N., \& Kitsantas, A. (2005). Using web-based pedagogical tools as scaffolds for self-regulated learning. Instructional Science, 33, 513-540. http://dx.doi.org/10.1007/s11251-005-1278-3.

Denzin, N. K., \& Lincoln, Y. S. (Eds.). (2005). Handbook of qualitative research (3rd ed.). Thousand Oaks: Sage.

Detterman, D. K. (1993). The case for the prosecution: transfer as an epiphenomenon. In D. K. Detterman \& R. J. Sternberg (Eds.), Transfer on trial: intelligence, cognition and instruction (pp. 1-24). Norwood: Ablex.

Dori, Y. J., \& Sasson, I. (2013). A three-attribute transfer skills framework - part l: establishing the model and its relation to chemical education. Chemistry Education Research and Practice (CERP), 14(4), 363-375.

Effat, A., \& Gillies, R. M. (2015). Social interactions that support students' self-regulated learning: a case study of one teacher's experiences. International Journal of Educational Research, 72, 14-25.

Flavell, J. (1979). Metacognitive and cognitive monitoring: a new area of cognitive development inquiry. American Psychologist, 34(10), 906-911. http://psycnet.apa.org/journals/amp/34/10/906.pdf.

Flavell, J. H. (1987). Speculations about the nature and development of metacognition. In F. E. Weiner \& R. H. Kluwe (Eds.), Metacognition, motivation, and understanding (pp. 21-29). Hillsdale: Lawrence Erlbaum.

Ford, J. K., Smith, E. M., Weissbein, D. A., Gully, S. M., \& Salas, E. (1998). Relationships of goal orientation, metacognitive activity, and practice strategies with learning outcomes and transfer. Journal of Applied Psychology, 83(2), 218-233. http://dx.doi.org/10.1037/0021-9010.83.2.218.

Forman, J., Creswell, J. W., Damschroder, L., Kowalski, C. P., \& Krein, S. L. (2008). Qualitative research methods: key features and insights gained from use in infection prevention research. American Journal of Infection Control, 36(10), 764-771.

Forsyth, B. R. (2012). Beyond physics: a case for far transfer. Instructional Science, 40, 515-535. http://dx.doi.org/10.1007/ s11251-011-9188-z.

Glaser, R. (1986). Training expert apprentices. In I. L. Goldstein, R. M. Gagne, R. Glaser, J. M. Royer, T. J. Shuell, \& D. L. Payne (Eds.), Learning research laboratory: proposed research issues (AFHRL-TP-85-54). Brooks AFB: Air Force Human Resources Laboratory, Manpower and Personnel Division

Hong, S., \& Jung, I. (2011). The distance learner competencies: a three-phased empirical approach. Educational Technology Research and Development, 59, 21-42. http://dx.doi.org/10.1007/s11423-010-9164-3.

Hsieh, F., \& Shannon, E. (2005). Three approaches to qualitative content analysis. Qualitative Health Research, 15(9), 1277-1288.

Hussein-Farraj, R., Barak, M., \& Dori, Y. J. (2012). Lifelong learning at the Technion: graduate students' perceptions of and experiences in distance learning. Interdisciplinary Journal of E-Learning and Learning Objects, 8, 115-135.

Kauffman, D. F. (2004). Self-regulated learning in web-based environments: instructional tools designed to facilitate cognitive strategy use, metacognitive processing, and motivational beliefs. Journal of Educational Computing Research, 30, 139-161.

Kramarski, B., \& Michalsky, T. (2010). Preparing preservice teachers for self-regulated learning in the context of technological pedagogical content knowledge. Learning and Instruction, 20, 434-447. http://dx.doi.org/10.1016/j. learninstruc.2009.05.003.

Lobato, J. (2008). Research methods for alternative approaches to transfer: implications for design experiments. In A. Kelly, R. A. Lesh, \& J. Y. Baek (Eds.), Handbook of design research methods in education (pp. 167-194). New York: Routledge.

McCormick, C. B. (2003). Metacognition and learning. In W. M. Reynolds \& G. E. Miller (Eds.), Handbook of psychology: educational psychology (pp. 79-102). Hoboken: Wiley.

McCrudden, M. T. (2011). Do specific relevance instructions promote transfer appropriate processing? Instructional Science, 39, 865-879. http://dx.doi.org/10.1007/s11251-010-9158-x.

Perkins, D. N., \& Salomon, G. (1988). Teaching for transfer. Educational Leadership, 46(1), 22-32.

Peterson, A., \& Roseth, C. J. (2016). Effects of four CSCL strategies for enhancing online discussion forums: social interdependence, summarizing, scripts, and synchronicity. International Journal of Educational Research, 76, 147-161.

Pintrich, P. (1999). The role of motivation in promoting and sustaining self-regulated learning. International Journal of Educational Research, 31, 459-470. http://dx.doi.org/10.1016/50883-0355(99)00015-4.

Pintrich, P. R. (2000). Multiple goals, multiple pathways: the role of goal orientation in learning and achievement. Journal of Educational Psychology, 92, 544-555. http://dx.doi.org/10.1037/0022-0663.92.3.544.

Rodicio, H. G., Sánchez, E., \& Acuña, S. R. (2013). Support for self-regulation in learning complex topic from multimedia explanations: do learners need extensive or minimal support? Instructional Science, 41, 539-553. http://dx.doi.org/ 10.1007/s11251-012-9243-4.

Ryan, A., \& Pintrich, P. R. (1998). Achievement and social motivational influences on help-seeking in the classroom. In S. Karabenick (Ed.), Strategic help seeking: implications for learning and teaching (pp. 117-139). Mahwah: Lawrence Erlbaum Associates.

Sasson, I., \& Dori, Y. J. (2012). Transfer skills and their case-based assessment. In B. J. Fraser, K. G. Tobin, \& C. J. McRobbie (Eds.), The second international handbook of science education (pp. 691-710). Dordrecht: Springer.

Schraw, G. (2006). Knowledge: structures and processes. In P. Alexander \& P. Winne (Eds.), Handbook of educational psychology (2nd ed., pp. 245-264). San Diego: Academic.

Schraw, G. (2009). A conceptual analysis of five measures of metacognitive monitoring. Metacognition and Learning, 4 , 33-43. http://dx.doi.org/10.1007/s11409-008-9031-3.

Schunk, D. H., \& Zimmerman, B. J. (Eds.). (1998). Self-regulated learning: from teaching to self-reflective practice. New York: The Guilford Press.

Selim, H. M. (2007). Critical success factors for e-learning acceptance: confirmatory factor models. Computers and Education, 49(2), 396-413. http://dx.doi.org/10.1016/j.compedu.2005.09.004. 
Spruce, R., \& Bol, L. (2015). Teacher beliefs, knowledge, and practice of self-regulated learning. Metacognition Learning, 10, $245-277$. Vázquez-Abad, J., Brousseau, N., Guillermina, W. C., Vézina, M., Martínez, A. D., \& de Verjovsky, J. P. (2004). Fostering distributed science learning through collaborative technologies. Journal of Science Education and Technology, 13(2), $227-232$.

Virnoche, L. (2008). Opening the gates to learning: How does the integration of learning styles and multiple intelligences support the learning and motivation of middle school students? UMI ProQuest Digital Dissertations (UMI No. 1457935).

Weinstein, C. E., \& Mayer, R. E. (1986). The teaching of learning strategies. In M. Wittrock (Ed.), Handbook of research on teaching (pp. 315-327). New York: Macmillan.

Wolters, C. A., \& Hussain, M. (2015). Investigating grit and its relations with college students' self-regulated learning and academic achievement. Metacognition and Learning, 10, 293-311.

Zimmerman, B. J. (1989). A social cognitive view of self-regulated academic learning. Journal of Educational Psychology, 81(3), 329-339. http://dx.doi.org/10.1037/0022-0663.81.3.329.

Zimmerman, B. J. (1995). Self-efficacy and educational development. In A. Bandura (Ed.), Self-efficacy in changing societies (pp. 202-231). New York: Cambridge Univ. Press.

Zimmerman, B. J. (2001). Theories of self-regulated learning and academic achievement. An overview and analysis. In B. J. Zimmerman \& D. H. Shunck (Eds.), Self-regulated learning and academic achievement: theoretical perspectives (pp. 1-37). Mahwah: Erlbaum.

Zohar, A., \& Dori, Y. J. (Eds.). (2012). Metacognition in science education: trends in current research. Dordrecht: Springer. 280.

Submit your manuscript to a SpringerOpen ${ }^{\circ}$ journal and benefit from:

- Convenient online submission

- Rigorous peer review

- Immediate publication on acceptance

- Open access: articles freely available online

- High visibility within the field

- Retaining the copyright to your article

Submit your next manuscript at $>$ springeropen.com 